Email : jkesislam@unisma.ac.id

Home Page : http://riset.unisma.ac.id/index.php/jki

\title{
FUNGSI KOGNITIF PEKERJA PARKIR TERMINAL BUS ARJOSARI KOTA MALANG
}

\author{
Shinta Kusumawati1, Rima Zakiyah2, Millah Mahfudhoh3 \\ Fakultas Kedokteran Universitas Islam Malang \\ Email: ShintaKusumawati@unisma.ac.id
}

\begin{abstract}
Abstrak
Latar belakang: Pencemaran lingkungan terbesar di Indonesia kurang lebih 70\% disebabkan oleh emisi kendaraan bermotor di udara. Partikel dalam polutan udara atau asap kendaraan berkaitan dengan fungsi yang dapat mempengaruhi fungsi kognisi dan struktur arteri meliputi carotid intima media thickness dan arterial stiffness. Selain itu juga berkaitan dengan faktor resiko kardiovaskuler yang berperan menyababkan gangguan kognisi, seperti homosistein, tekanan darah dan diabetes. Terminal bus arjosari adalah terminal tipe A yang terbesar di Kota Malang dengan potensi polusi udara yang tinggi akibat kendaran umum.
\end{abstract}

Tujuan: Mengetahui fungsi kognitif pekerja parkir Terminal bus Arjosari Kota Malang

Metode: Penelitian yang digunakan deskriptif-analitik. Penilaian fungsi kognisi berdasarkan MoCaINA, dan pekerja parkir terminal yang diteliti beraktivitas di lapangan parkir terminal bus Arjosari Kota Malang.

Hasil: Didapatkan 21 subjek penelitian yang sebagian besar berusia 45 sampai 54 tahun, dengan tingkat pendidikan lulus SD 38,1\% dan lulus SMA 38,1\%. Data antoprometri BMI normal 52,4\% dan overweight $38,1 \%$. Tekanan darah normal semua subjek dan gula darah normal. Kebiasaan merokok 47,6\% dan tidak merokok 52,4\%. Lama bekerja $>10$ tahun 66,6\%, dan $<10$ tahun 33,4\%. Penilaian kognitif berdasarkan skor MoCa INA didapatkan normal (skor $\geq 26$ ) $19 \%$ dan abnormal (<26) $81 \%$ dengan nilai abnormal kognitif lebih banyak pada pekerja dengan lama bekerja>10 tahun sebanyak $59 \%$

Kesimpulan: Adanya penurunan kognitif pada pekerja parkir bus terminal arjosari sebanyak $81 \%$ pekerja dengan penilaian skor MocaINA $<26$.

\footnotetext{
Abstract

Background: The biggest environmental pollution in Indonesia is about $70 \%$ air pollution caused by motor vehicle emissions. Particles in pollutant air or vehicle fumes are related to the function and structure of arteries that can affect cognitive functions including carotid intima media thickness and arterial stiffness. In addition, it is also related to cardiovascular risk factors that play a role in causing cognitive impairments, such as homocysteine, blood pressure and diabetes. Arjosari bus station is the largest terminal in Malang City include type A.

Objective: To determine the cognitive function of parking workers at the Arjosari Bus Station in Malang City

Method: This research is descriptive research. Assessment of cognitive function based on MoCAINA and terminal parking workers is workers who are active in the arjosari bus terminal parking field.

Results: This study found 21 research subjects with characteristics, many of which were aged 45 to 54 years, with elementary school education of $38.1 \%$ and high school $38.1 \%$. The Antoprometry data is $52.4 \%$ normo weight and $38.1 \%$ overweight. Normal blood pressure of all subjects and normal blood sugar. $47.6 \%$ smoking habits and no smoking 52.4\%. Duration> 10 years 66.6\%, and $<10$ years 33.4\%. Cognitive assessment based on the MoCaINA score was normal (score $\geq 26$ ) $19 \%$ and abnormal $(<26) 81 \%$ with more abnormal cognitive values in workers with a length of work> 10 years as much as $59 \%$
} 
Conclusion: There is a cognitive decline in arjosari bus station parking workers as much as $81 \%$ of workers with a MocaINA score $<26$.

\section{PENDAHULUAN}

Perkembangan ilmu pengetahuan dan teknologi meningkatkan jumlah perindustrian dan alat transportasi sehingga menyebabkan tingkat pencemaran udara makin meningkat pula. Pencemaran udara termasuk pencemaran terbesar di Indonesia dimana $70 \%$ berasal dari emisi kendaraan bermotor ${ }^{1}$. Pencemaran udara dapat terjadi dimana-mana, misalnya di dalam rumah, sekolah, dan kantor. Pencemaran ini sering disebut pencemaran dalam ruangan (indoor pollution). Sementara itu pencemaran di luar ruangan (outdoor pollution) berasal dari emisi kendaraan bermotor, industri, perkapalan, dan proses alami oleh makhluk hidup ${ }^{1}$. Pencemaran udara berkaitan dengan peningkatan resiko penyakit pernafasan, kardiovaskuler, dan serebrovaskuler ,tetapi hubungan dengan fungsi dan gangguan kognitif belum jelas ${ }^{2}$. Partikel dalam pollutan udara atau asap kendaraan berkaitan dengan fungsi dan struktur arteri yang dapat mempengaruhi fungsi kognisi meliputi carotid intima media thickness dan arterial stiffness. Selain itu juga berkaitan dengan faktor resiko kardiovaskuler yang berperan menyababkan gangguan kognisi, seperti homosistein, tekanan darah dan diabetes. Paparan polusi udara berkaitan dengan gangguan fungsi kognitif pada semua usia dan peningkatan resiko demensia alzeimer dan demensia lainnya pada kehidupan berikutnya . Hal ini berkaitan dengan polutan kendaraan bermotor seperti nitrogen dioxide, nitrous oxide, karbon hitam, dan cairan dan bahan logam dalam udara yang berukuran kecil yang disebaut particulate matter $(\mathrm{PM})^{3}$. PM berkontribusi terhadap penyakit kardiovaskuler dan serebrovaskuler melalui mekanisme inflamasi sistemik, aktivasi koagulasi direk dan indirek dan translokasi langsung kedalam sirkulasi sistemik. Sumber PM antara lain pembakaran mesin dan proses industri, asap kendaraan ,merokok, kebakaran, gunung berapi, dan badai debu ${ }^{4}$.

\section{METODE PENELITIAN}

Penelitian ini menggunakan desain penelitian diskriptif analitik. Desain penelitian ini bertujuan untuk mengetahui gambaran fungsi kognitif yang diukur menggunakan MOCA INA pada pekerja parkir bus Arjosari. Penelitian ini dilakukan di terminal Bus Arjosari Kota Malang . Penelitian ini mendapat surat laik etik dari Komisi Etik Penelitian Kesehatan Fakultas Kedokteran Universitas Brawijaya dengan

nomor 10/EC/KEPK-S1/01/2019 dan disetujui pada tanggal 17 Januari 2019.

Penelitian ini menggunakan subjek manusia, berjumlah 21 orang. Subjek penelitian ini adalah pekerja yang beraktivitas di lapangan parkir terminal bus arjosari, serta kooperatif dan bersedia menjadi responden. Penelitian dilaksanakan pada bulan Januari 2019.

Wawancara dilakukan secara langsung kepada masing-masing pekerja. Instrument wawancara menggunakan kuisioner $\mathrm{MoCa}$ INA (Montreal Cognitive Assessment Versi Indonesia). Responden hanya menjawab pertanyaan sedangkan peneliti mengajukan pertanyaan yang ada di kuisioner. Hal ini sesuai dengan prosedur kuisioner untuk penilaian fungsi kognitif dan bertujuan agar pertanyaan mudah dipahami oleh responden dan jawaban bisa sesuai dengan yang diharapkan peneliti. 


\section{HASIL DAN ANALISA}

Adapun karakteristik sampel penelitian dapat dilihat pada tabel 1 .

Tabel 1. Karakteristik Subjek

\begin{tabular}{|c|c|c|c|}
\hline No. & Karakteristik Sampel & Frekuensi & $\%$ \\
\hline \multirow[t]{6}{*}{1.} & Usia & & \\
\hline & $35-39$ & 1 & 4,8 \\
\hline & $40-44$ & 2 & 9,6 \\
\hline & $45-49$ & 7 & 33,3 \\
\hline & $50-54$ & 7 & 33,3 \\
\hline & $55-59$ & 4 & 19 \\
\hline \multirow[t]{4}{*}{2.} & $\mathrm{BMI}$ & & \\
\hline & Underweight & 2 & 9,5 \\
\hline & Normal & 11 & 52,4 \\
\hline & Overweight & 8 & 38,1 \\
\hline \multirow[t]{2}{*}{3.} & Tekanan Darah & & \\
\hline & Normal & 21 & 100 \\
\hline \multirow[t]{2}{*}{4.} & Gula Darah Sewaktu & & \\
\hline & $<140 \mathrm{mg} / \mathrm{dL}$ & 21 & 100 \\
\hline \multirow[t]{3}{*}{5.} & Faktor Resiko & & \\
\hline & Merokok & 10 & 47,6 \\
\hline & Tidak Merokok & 11 & 52,4 \\
\hline \multirow[t]{5}{*}{6.} & Lama Pendidikan & & \\
\hline & $\mathrm{SD}$ & 8 & 38,1 \\
\hline & SMP & 1 & 4,8 \\
\hline & SMA & 8 & 38,1 \\
\hline & Sarjana & 4 & 19 \\
\hline \multirow[t]{5}{*}{7.} & Lama Bekerja & & \\
\hline & 1-10 Tahun & 7 & 33,3 \\
\hline & 11-20 Tahun & 2 & 9,5 \\
\hline & 21-30 Tahun & 8 & 38,1 \\
\hline & 31-40 Tahun & 4 & 19 \\
\hline
\end{tabular}

Pada tabel 1 menunjukkan subjek penelitian banyak berusia petengahan berkisar 45-54 tahun $(66,6 \%)$, dan terdapat subyek merokok dan tidak merokok yang dapat dikatakan seimbang. Tingkat pendidikan pada subyek di penelitian ini terbanyak pada tingkat pendidikan SD dan SMA. Karakteristik subyek pada penelitian ini juga dikelompokkan berdasarkan lama bekerja, dimana subyek banyak bekerja lebih dari 10 tahun $(66,6 \%)$.

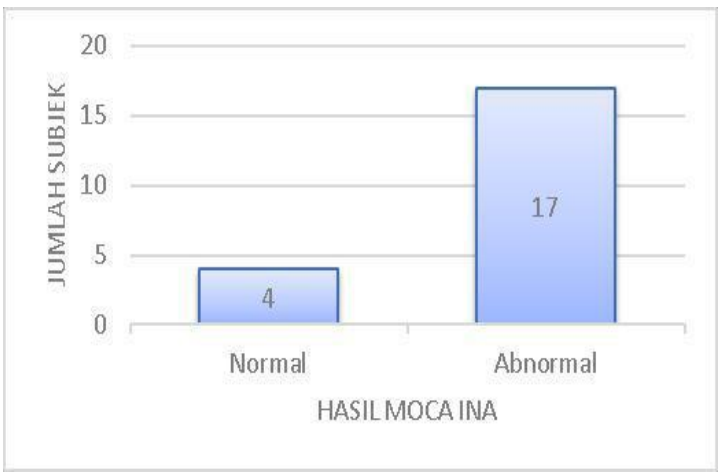

Gambar 1. Hasil Penilaian MoCa INA petugas parkir terminal bus arjosari Kota Malang. MoCa INA (Montreal Cognitive Assessment Versi Indonesia). MoCa INA normal skor bernilai 26 atau lebih. MoCa INA Abnormal skor bernilai kurang dari 26
Pada gambar 1 menunjukkan penilaian fungsi kognitif $\mathrm{MoCa}$ INA pada pekerja parkir terminal bus menunjukkan skor MoCa INA abnormal (skor <26) lebih banyak (17 subjek) dibandingkan MoCA INA normal >26) hanya 4 orang dari keseluruhan subjek penelitian

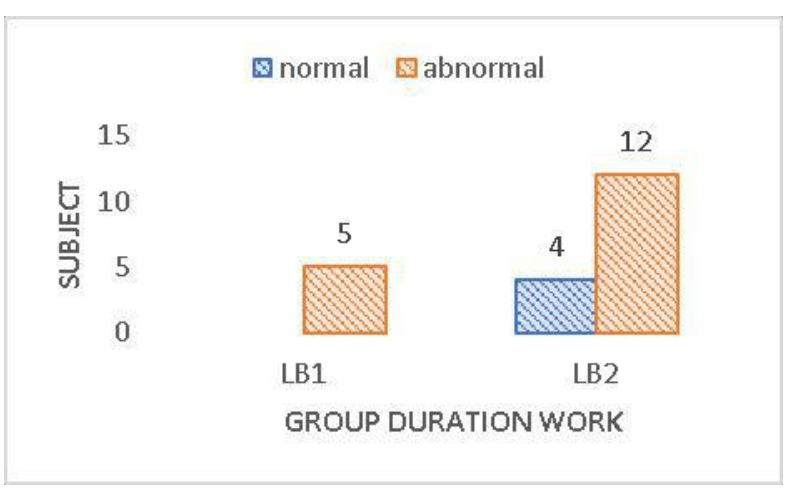

Gambar 2. Penilaian MoCa INA berdasarkan kelompok lama bekerja. LB1 (Lama Bekerja <10 tahun). LB2 (Lama Bekerja $\geq 10$ tahun )

Pada gambar 2 menunjukkan penilaian MoCa INA normal pada kelompok LB 2 sebanyak 4 orang sedangkan pada LB 1 semua abnormal. Tetapi skor MoCa INA abnormal lebih banyak pada kelompok LB 2 (12 orang) dibanding LB 1 (5 orang). Sedangkan pada uji analisis Spearman hubungan LB2 dan MOcA INA tidak signifikan $(\mathrm{p}>0,05)$.

\section{PEMBAHASAN}

Pada penelitian ini penilaian fungsi kognisi dengan menggunakan MoCa INA menunjukkan hasil skor abnormal sebanyak 17 orang dibandingkan skor MoCa INA normal sebanyak 5 orang pada subjek penelitian yang banyak berusia pertengahan sekitar 45-54 tahun. Hal ini menunjukkan subjek penelitian lebih banyak mengalami gangguan kognitif berdasarakan penilaain dengan menggunakan MoCa INA. Tekanan darah dan gula darah pada subjek penelitian semua normal.

Polutan udara dan PM adalah sumber tetap penyebab neuroinflamasi dan reactive oxygen species (ROS), dimana proses ini sangat berkaitan dengan pathogenesis penyakit SSP (Sistem saraf Pusat). Paparan terhadap 
polutan udara berkaitan dengan peningkatan disfungsi kognitif dan peningkatan proses neurodegenerative yang mendasari Alzeimer (AD) dan Parkinson (PD). Pada anak-anak dan orang tua yang terpapar polutan udara menunjukkan tanda disfungsi kognitif, tetapi pada penelitian kohort pada usia pertengan sangat sedikit kejadiannya 5 . Pada penelitian ini subjek lebih banyak pada usia pertengahan. Menurut Kilian (2018) paparan polusi udara berkaitan dengan gangguan fungsi kognisi pada semua usia dan peningkatan resiko demensia alzeimer dan demensia lainnya pada kehidupan berikutnya.

Penilaian fungsi kognitif berdasarkan kelompok lama bekerja menunjukkan bahwa skor MoCa INA abnormal lebih banyak terjadi pada kelompok lama bekerja $\geq 10$ tahun (12 orang), sedangkan pada kelompok lama bekerja $<10$ tahun sebanyak 5 orang. Hal ini dikarenakan mayoritas $(66,6 \%)$ subjek penelitian sebesar bekerja > 10 tahun. Hal ini berarti subjek penelitian yang bekerja $>10$ tahun banyak yang mengalami gangguan kognitif berdasarakan penilaian dengan $\mathrm{MoCa}$ INA. Semakin lama durasi bekerja semakin sering subjek terpapar asap kendaraan di tempat bekerja sehingga risiko gangguan kognitif akibat pencemaran udara lebih tinggi. Tetapi pada penelitian ini tidak menilai faktor lingkungan lainnya yang dapat terlibat dalam terjadinya proses neurodegeneratif seperti logam berat, kontaminasi bahan beracun dalam minuman, dan bahan kimia pertanian yang terpapar pada makanan. Paparan kronis faktor lingkungan dapat meningkatkan resiko perkembangan AD baik pada studi epidemologi maupun pada binatang. Pada penelitian in vivo pada tikus paparan PM akut dapat menyebabkan respon inflamasi otak seperti sitokin proinflamsi IL $1 \alpha$ dan TNF, respon glial dan aktivasi $\mathrm{NF}-\kappa \beta$ dan factor transkripsi Ap 1. Sel glia terutama mikroglia dan astrosit juga berperan dalam patogenis AD. Paparan PM juga dapat merubah aktivasi sel glia sehingga beresiko menyebabkan AD. Paparan PM 2,5 yang lebih lama (30-39 minggu) pada tikus menyebabkan hilangnya densitas dendrit secara signifikan pada hipokampus CA 1 yang sangat berkaitan dengan gangguan kognitif. Kerusakan vaskuler otak dan efek sistemik seperti hipertensi juga berperan penting terhadap kognitif pada paparan $\mathrm{PM}^{3}$.

Hubungan lama bekerja dan Penilaian fungsi kognitif dengan $\mathrm{MoCa}$ INA menunjukkan fungsi kognitif abnormal banyak pada kelompok LB2 tetapi berdasrakan uji analisi dengan Spearman test hubungannya tidak signifikan $(\mathrm{P}>0,05)$ yang berarti lama bekerja $\geq 10$ tahun dengan fungsi kognitif abnormal tidak berhubungan signifikan. Hal ini dapat disebabkan gangguan kognitif baik pada kelompok lama bekerja $\geq 10$ tahun dan $<10$ tahun tidak hanya disebabkan oleh lamanya paparan asap kendaraan bermotor, juga dapat disebabkan faktor lain yang dapat dimodifikasi termasuk gaya hidup, riwayat penyakit, riwayat pendidikan, kebiasaan makan dan paparan terhadapa bahan berbahaya di lingkungan dan tempat kerja. Faktor resiko lingkungan seperti bahan logam dan kandungan bahan toksik dalam air minum, bahan pestisida dalam makanan, dan polusi udara yang terpapar kronis dapat meningkatkan resiko penyakit alzeimer berdasarkan studi epidemologi dan hewan coba. ${ }^{3}$

Gangguan kognitif yang terjadi pada subjek penelitian bisa disebabkan oleh paparan kandungan bahan toksik dalam asap kendaraan dan faktor lingkungan lainnya yang terkait penurunan gangguan kognitif dimana masih belum diteliti saat ini.

\section{KESIMPULAN DAN SARAN}

Didapatkan gangguan kognitif pada pekerja parkir terminal bus arjosari kota Malang terutama pada pekerja yang bekerja lebih dari 10 tahun. Perlu dilakukan penelitian lebih lanjut terkait asap kendaraan seperti efek logam berat termasuk ukuran particulate matter, faktor lingkungan dan dampak pada sitokin proinflamasi pada tubuh subjek penelitian terutama sistem respirasi dan system kardiovaskuler. 


\section{REFERENSI}

1. Sugiarti. Gas Pencemar Udara Dan Pengaruhnya Bagi Kesehatan Manusia. Jurnal Chemica Vol. 10 Nomor I Juni 2009, $50-58$

2. Clifford A,et al. Exposure to air pollution and cognitive functioning across the life course.A systematic literature review. Environmental Research. Vol 147,2016,383-398.

3. Kilian, J. Kitazawa,M. Review Article The emerging risk of exposure to air pollution on cognitive decline and Alzheimer's disease-Evidence from epidemiological and animal studies. Biomedical Journal.2018.141-162

4. Anderson,J.O., Thundiyil,J.G.,Stolbach,A. Clearing the Air: A Review of the Effects of Particulate Matter air Pollution on human Health. Journal of Medical Toxicology.2012;8(2),166-175.

5. Robin et al.Cinical Effects of Air Pollution on the Central Nervous System; A Review. J Clin Neurosci.2017 Sep;43:16-24

6. Effects Of Air Pollution. Environmental Pollution. Elsevier. Heraklion. 2007

7. Karri, V., Schuhmacher, M., Kumar, V.,. Heavy metals ( $\mathrm{Pb}, \mathrm{Cd}$, As and $\mathrm{MeHg})$ as risk factors for cognitive dysfunction; $\mathrm{A}$ general review of metal mixture mechanism in brain. 2016

8. Ratnaike, R.N. Acute and chronic arsenic toxicity. Postgrad. Med. J. 2003

9. Lasley, S.M., Green, M. C., Gilbert, M.E.,. Rat hippocampal NMDA receptor binding as a function of chronic lead exposure level. Neurotoxicol. Teratol. 2001

10. Minami, A. Takeda, A, Nishibaba, D, et al. Cadmium toxicity in synaptic neurotransmission in the brain. ELSEVIER. 2001

11. Crum RM, Anthony JC, Bassett SS, et al: Population-based norms for the MiniMental State Examination by age and educational level. JAMA. 1993

12. Jia JP, Jia JM, Zhou WD, et al. Differential acetylcholine and choline concentrations in the cerebrospinal fluid of patients with Alzheimer's disease and vascular dementia. Chin Med J. 2004

13. Costa P, Goncalves J, et al.,. Curcumin attenuates memory deficits and the impairment of cholinergic and purinergic signaling in rats chronically exposed to cadmium. Environ Toxicol. 2017

14. Son yp, Wang L, Poyil P, et al. Cadmium induces carcinogenesis in BEAS-2B cells through ROS- dependent activation of PI3K/AKT/GSK-3 $\beta / \beta$-catenin signaling. Toxicol Appl Pharmacol. 2012

15. Hongyu $\mathrm{Li}$ et al.,. Associations between blood cadmium levels and cognitive function in a crosssectional study of US adults aged 60 years or older. BMJ Open. 2018

16. Hart, R. P., Rose, C. S., and Hamer, R. M. Neuropsychological effects of occupational exposure to cadmium. J. Clin. Exp. Neuropsychol. 1989

17. Sharma, H., Rawal, N., \& Mathew, B. B. The charracteristics, Toxicity, and Effects of Cadmium, International Journal of Nanotechnology and Nanoscience. 2015

18. Endrinaldi. Logam-Logam Berat Pencemar Lingkungan Dan Efek Terhadap Manusia. Jurnal kesehatan masyarakat. 2010 